\title{
Article \\ The Efficacy of Selected Sodium Hypochlorite Heating Methods for Increasing and Maintaining Its Intracanal Temperature- An Ex Vivo Study
}

\author{
Roberto De Santis ${ }^{1}$, Flavia Iaculli ${ }^{2, *}$, Vincenzo Lodato ${ }^{2}$, Vito Gallicchio ${ }^{2} \mathbb{D}$, Michele Simeone ${ }^{2}$, \\ Gianrico Spagnuolo $^{2}$ and Carlo Rengo ${ }^{3}$ (D)
}

check for

updates

Citation: De Santis, R.; Iaculli, F.;

Lodato, V.; Gallicchio, V.; Simeone, M.; Spagnuolo, G.; Rengo, C. The Efficacy of Selected Sodium

Hypochlorite Heating Methods for Increasing and Maintaining Its

Intracanal Temperature-An Ex Vivo Study. Appl. Sci. 2022, 12, 891. https://doi.org/10.3390/app12020891

Academic Editor: Vittorio Checchi

Received: 24 December 2021

Accepted: 14 January 2022

Published: 16 January 2022

Publisher's Note: MDPI stays neutral with regard to jurisdictional claims in published maps and institutional affiliations.

Copyright: (C) 2022 by the authors. Licensee MDPI, Basel, Switzerland. This article is an open access article distributed under the terms and conditions of the Creative Commons Attribution (CC BY) license (https:// creativecommons.org/licenses/by/ $4.0 /)$.
1 IPCB-CNR Institute for Polymers, Composites and Biomaterial, 80125 Naples, Italy; rosantis@unina.it

2 Department of Neuroscience and Reproductive and Odontostomatological Sciences, University of Naples "Federico II", 80131 Naples, Italy; lodatovincenzo@gmail.com (V.L.); vito.gallicchio@unina.it (V.G.); michele.simeone@unina.it (M.S.); gspagnuo@unina.it (G.S.)

3 Department of Prosthodontics and Dental Materials, School of Dental Medicine, University of Siena, 53100 Siena, Italy; carlorengo@alice.it

* Correspondence: flavia.iaculli@unina.it

\begin{abstract}
Background: Enhancement of the temperature of sodium hypochlorite ( $\mathrm{NaOCl})$ solution would increase its cleaning potential and decontamination of the root canal system. Therefore, the aim of the present in vitro investigation was to compare the efficacy of different methods of $\mathrm{NaOCl}$ heating by evaluating the temperature profiles developed at different levels of the root canal system. Methods: Five thermocouples were applied at different levels of the root canal system of extracted human premolars. $\mathrm{NaOCl}$ solution was heated according to two methods: extraoral heating $\left(50{ }^{\circ} \mathrm{C}\right.$, $60^{\circ} \mathrm{C}$, and $70^{\circ} \mathrm{C}$ ) using a magnetic hotplate heater and intracanal heating by F-06, XF-30/04, and ML-12 pluggers at $100^{\circ} \mathrm{C}, 150{ }^{\circ} \mathrm{C}$, and $180^{\circ} \mathrm{C}$. Results: The extraoral heating method was ineffective to produce a significant temperature increase at the root apex. Comparable results were obtained using the intracanal heating method through the ML-12 plugger that showed slightly better results only when set at $180{ }^{\circ} \mathrm{C}$. On the other hand, negligible differences were observed in terms of temperature maintenance at several levels of the root between the F-06 and XF-30/04 pluggers, even though the time intervals were higher in case of XF-30/04. Conclusions: The intracanal heating method provided a better temperature persistence in the middle third of the root canal system. Conversely, extraoral heating was ineffective to produce a significant temperature increase at the apex of the root. Comparable results were obtained even using the ML-12 plugger.
\end{abstract}

Keywords: endodontics; heating; irrigants; root canal system; sodium hypochlorite; thermocouples

\section{Introduction}

Endodontic success is strictly related to the removal of pulp tissue and to the disinfection of root canal system that may be colonized by microorganisms [1]. Irrigation is reported to have an important antimicrobial/antibiofilm effect through the whole root canal, as well as the ability to remove the smear layer and/or debris produced by mechanical instrumentation [2,3]. Moreover, the use of irrigants may enhance the cutting ability of endodontic files decreasing their friction with dentinal tissue as well as the risk of fractures $[3,4]$.

The irrigation procedure in endodontics is clinically based on sodium hypochlorite $(\mathrm{NaOCl})$, due to its antibacterial effects and ability to dissolve the organic tissue, coupled with ethylenediaminetetraacetic acid (EDTA), used to remove the smear layer. Finally, the rinsing agents may be used with different effective techniques to promote deep penetration into the entire anatomical aspect of the endodontic canal system, even those not reached by mechanical instrumentation [5]. The correct combination of endodontic irrigants and mechanical preparation techniques would contribute to provide an ideal cleaning [6]. 
Temperature has a positive effect on the antibacterial and lytic action of $\mathrm{NaOCl}$ [7]; indeed, an enhancement in the temperature of $\mathrm{NaOCl}$ solution would increase the cleaning potential as well as the decontamination effect of the root canal system [7]. In addition, hot $\mathrm{NaOCl}$ solution removes organic debris from dentin crisps better than unheated solution [8]. $\mathrm{NaOCl}$ at $25{ }^{\circ} \mathrm{C}$ used for five minutes was demonstrated to be effective in the elimination of Enterococcus faecalis, showing a 100-fold increase in its efficacy [9]. In addition, preheating to $37^{\circ} \mathrm{C}$ enhances $\mathrm{NaOCl}$ effectiveness on Candida albicans at five minutes of contact time showing a significant antifungal property [9]. Moreover, heating of $\mathrm{NaOCl}$ may allow the use of a less concentrated solution; indeed, the ability of $\mathrm{NaOCl}$ to dissolve human dental pulp at $1 \%$ and at a temperature of $45^{\circ} \mathrm{C}$ is reported to be equivalent to that at $5.25 \%$ and $20^{\circ} \mathrm{C}$ [10]. The enhancement of the temperature of $\mathrm{NaOCl}$ may be obtained through extraoral (in special containers or by preheating of a syringe), intracanal using heat carriers (pluggers), or by means of ultrasonic inserts or laser devices.

Therefore, the aim of the present in vitro investigation was to compare the efficacy of different methods of $\mathrm{NaOCl}$ heating by evaluating the temperature profiles developed at different levels of the root canal system.

\section{Materials and Methods}

\subsection{Sample Preparation}

Twelve human single-rooted and one canal second lower premolars extracted for orthodontic reasons, free of caries or cracks, were selected for this study. The study was approved by the Ethics Committee of the University of Naples Federico II (protocol n. 1372017). The freshly extracted teeth were placed in 5.25\% water solution of sodiumhypochlorite $(\mathrm{NaOCl})$ for $5 \mathrm{~min}$ and stored in $0.9 \%$ saline solution at a temperature of $4{ }^{\circ} \mathrm{C}$. Root canal treatment was performed in each tooth using a rotary Protaper Next system (Dentsply Maillefer, Tulsa, OK, USA) until the X3 File reached the working length (WL). Disinfection of the canals was obtained using 5.25\% NaOCl and 17\% EDTA. Then, standardized holes were created on the root surfaces 5 and $10 \mathrm{~mm}$ above the apex by a high-speed round burr under abundant irrigation.

\subsection{Experimental Setup}

Five K-type thermocouples (RS components, Corby, UK) for each tooth were applied as follows: 3 were inserted through holes drilled from the root surface to the root canal (Figure 1a) and positioned at the apical foramen (Ta), at the apical third $5 \mathrm{~mm}$ from the apex $(\mathrm{T} 5 \mathrm{~mm})$, and at $10 \mathrm{~mm}$ from the apex (T10mm), respectively (Figure 1b); 1 thermocouple was applied on the radicular external surface at $3 \mathrm{~mm}$ from the anatomic apex (Text) (Figure 1b); the last was inserted in the root canal (Tc) at the cervical third level (Figure 1b). Then, each specimen was cemented with resin (Duralay, Reliance Dental Manufacturing LLC, Alsip, USA) into an aluminum tube (Figure 1c), and a thermo-controlled heater (ThermoBlock system, Falc, Genova, Italy) containing an aluminum block (Figure 1d) was used to control the temperature of the tooth environment $\left(37^{\circ} \mathrm{C}\right)$.

Thermocouples were connected to the NI DAC interface (MOD National Instruments Corporation, Austin, TX, USA), and signals were recorded through the LabView system (MOD National Instruments Corporation, Austin, TX, USA) at a rate of 10 points per second for $300 \mathrm{~s}$.

Then, $5 \%$ water solution of $\mathrm{NaOCl}$ was heated according to 2 methods: extraoral heating using a magnetic hotplate heater (MS-H-PRO+, DLAB, Scientific Inc., City of Industry, CA, USA) and intracanal heating by System B (SybronEndo, Kerr Corporation, Detroit, MI, USA). For the extraoral heating technique, a glass beaker containing $25 \mathrm{~mL}$ of $5 \% \mathrm{NaOCl}$ water solution was heated at $50{ }^{\circ} \mathrm{C}, 60{ }^{\circ} \mathrm{C}$, and $70{ }^{\circ} \mathrm{C}$. Then, $5 \mathrm{~mL}$ of the heated $\mathrm{NaOCl}$ solution was aspired into using a $5 \mathrm{~mL}$ plastic syringe supporting a $30-\mathrm{G}$ irrigation needle (Ultradent Products Inc., South Jordan, UT, USA) and immediately injected into the root canal. Conversely, F-06 (tip diameter $0.50 \mathrm{~mm} /$ conicity 06), XF-30/04 (tip diameter $0.40 \mathrm{~mm} /$ conicity 04 ), and ML-12 (tip diameter $0.50 \mathrm{~mm} /$ conicity 12) pluggers 
(SybronEndo, Kerr Corporation, Detroit, MI, USA) were used for intracanal heating and temperature settings at $100{ }^{\circ} \mathrm{C}, 150{ }^{\circ} \mathrm{C}$, and $180^{\circ} \mathrm{C}$ were investigated.
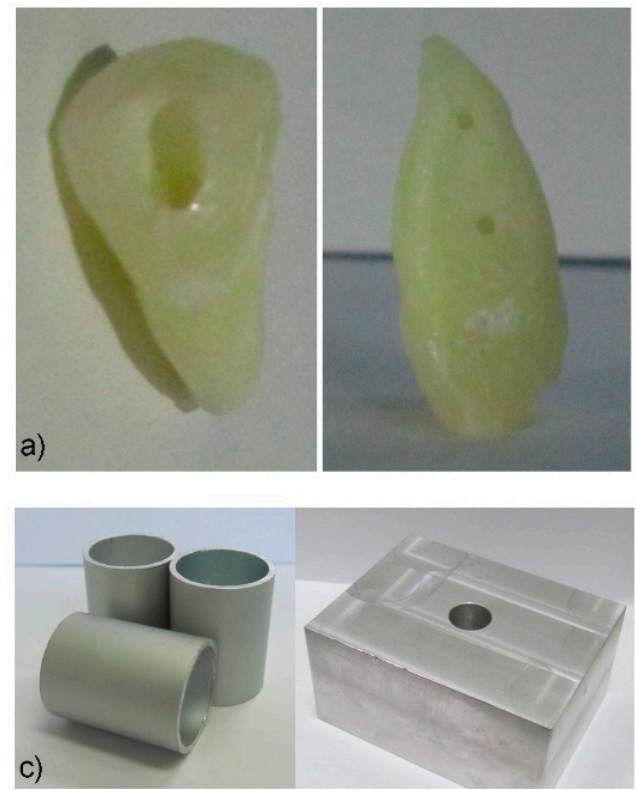
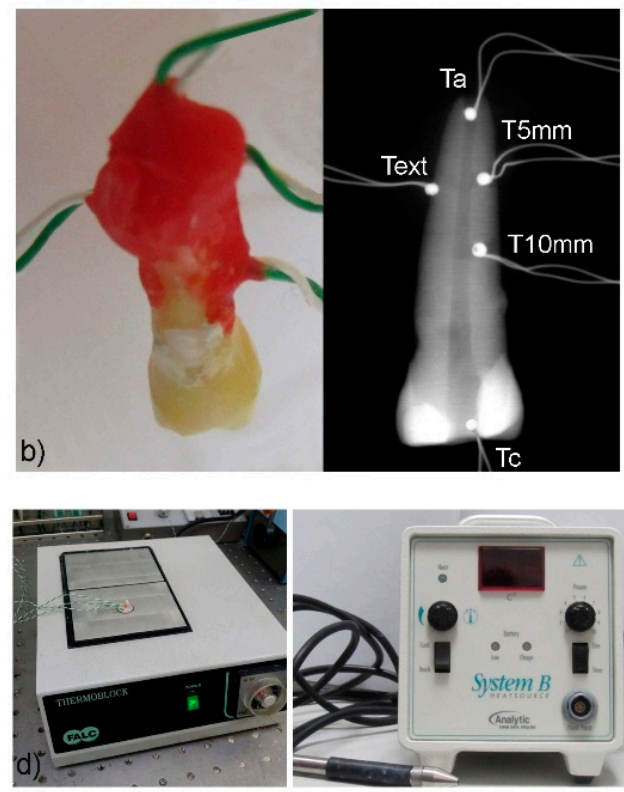

Figure 1. Specimen preparation and setup. Instrumented root canal and holes drilled through the root (a); thermocouple placement (b); aluminum tubes and block (c); and thermostatic and heating systems $(\mathbf{d})$.

A thermocamera Fluke Ti10 (Fluke Corporation, Everett, WA, USA) was used to record the effective temperature profiles along each plugger, and temperature analysis was performed through the SmartView software (Fluke Corporation, Everett, WA, USA).

Analysis of variance through the OriginLab Pro7 software (OriginLab Corporation, Northampton, MA, USA) at a significance level of 0.05 using the Bonferroni method was performed to compare temperature data.

\section{Results}

\subsection{Extraoral Heating}

Temperature profiles in the different regions of the tooth through the extraoral heating method at $50{ }^{\circ} \mathrm{C}, 60^{\circ} \mathrm{C}$, and $70^{\circ} \mathrm{C}$ are reported in Figure 2 .

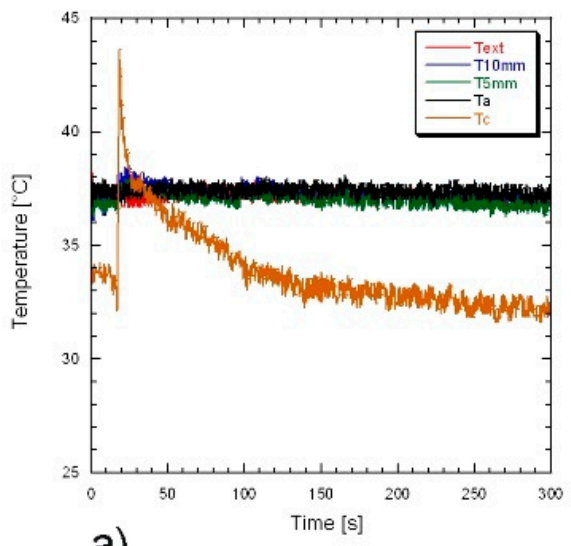

a)

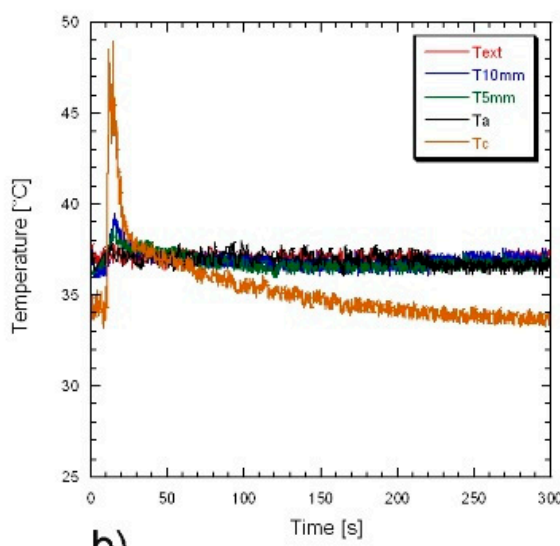

b)

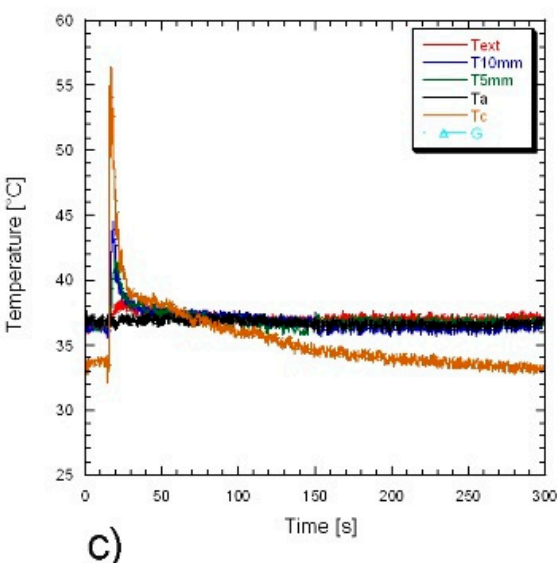

c)

Figure 2. Temperature profiles in different regions of the tooth by extraoral heating of sodiumhypochlorite at $50{ }^{\circ} \mathrm{C}(\mathbf{a}), 60^{\circ} \mathrm{C}(\mathbf{b})$, and $70{ }^{\circ} \mathrm{C}(\mathbf{c})$. 
A marked temperature drop, quantified by the difference between the temperature setting of the extraoral heating system and the peak temperature measured by the thermocouple (Tc) positioned at the cervical third level (Figure 2), was recorded as $\mathrm{NaOCl}$ solution was injected into the root canal. The temperature drop of $6.5^{\circ} \mathrm{C}\left( \pm 1.9^{\circ} \mathrm{C}\right), 11.3^{\circ} \mathrm{C}$ $\left( \pm 2.2^{\circ} \mathrm{C}\right)$, and $13.7^{\circ} \mathrm{C}\left( \pm 2.8^{\circ} \mathrm{C}\right)$ was obtained at heating of $50^{\circ} \mathrm{C}, 60^{\circ} \mathrm{C}$, and $70{ }^{\circ} \mathrm{C}$, respectively. Concerning extraoral heating at $50^{\circ} \mathrm{C}$ (Figure 2a), a negligible temperature increase was recorded by the Text, T10mm, and T5mm thermocouples suggesting that the $\mathrm{NaOCl}$ solution quickly cools down in all the root regions. A slight temperature increase of about $2{ }^{\circ} \mathrm{C}$ was observed as $\mathrm{NaOCl}$ solution was heated to $60^{\circ} \mathrm{C}$ (Figure $2 \mathrm{~b}$ ). Finally, in case of $\mathrm{NaOCl}$ solution heated at $70^{\circ}$, temperature peak levels of $44{ }^{\circ} \mathrm{C}\left( \pm 2.5^{\circ} \mathrm{C}\right)$ and $42{ }^{\circ} \mathrm{C}$ $\left( \pm 2.6^{\circ} \mathrm{C}\right)$ were recorded by the T10mm and T5mm thermocouples, respectively (Figure 2c).

\subsection{Intracanal Heating}

Temperature profiles along the F-06, $\mathrm{XF}-30 / 04$, and ML-12 pluggers at the temperature settings of $100{ }^{\circ} \mathrm{C}, 150{ }^{\circ} \mathrm{C}$, and $180^{\circ} \mathrm{C}$ are reported in Figure 3 . Higher temperature peak levels closer to the setting temperatures $\left(102^{\circ} \mathrm{C}, 143^{\circ} \mathrm{C}\right.$, and $155^{\circ} \mathrm{C}$, at settings of $100{ }^{\circ} \mathrm{C}$, $150{ }^{\circ} \mathrm{C}$, and $180{ }^{\circ} \mathrm{C}$, respectively) were detected for the $\mathrm{XF}-30 / 04$ plugger (Figure $3 \mathrm{~b}$ ). Conversely, the ML-12 plugger provided much lower temperature peak levels than the setting temperatures $\left(54{ }^{\circ} \mathrm{C}, 65^{\circ} \mathrm{C}\right.$, and $71^{\circ} \mathrm{C}$, at settings of $100^{\circ} \mathrm{C}, 150^{\circ} \mathrm{C}$, and $180{ }^{\circ} \mathrm{C}$ respectively) (Figure 3c).
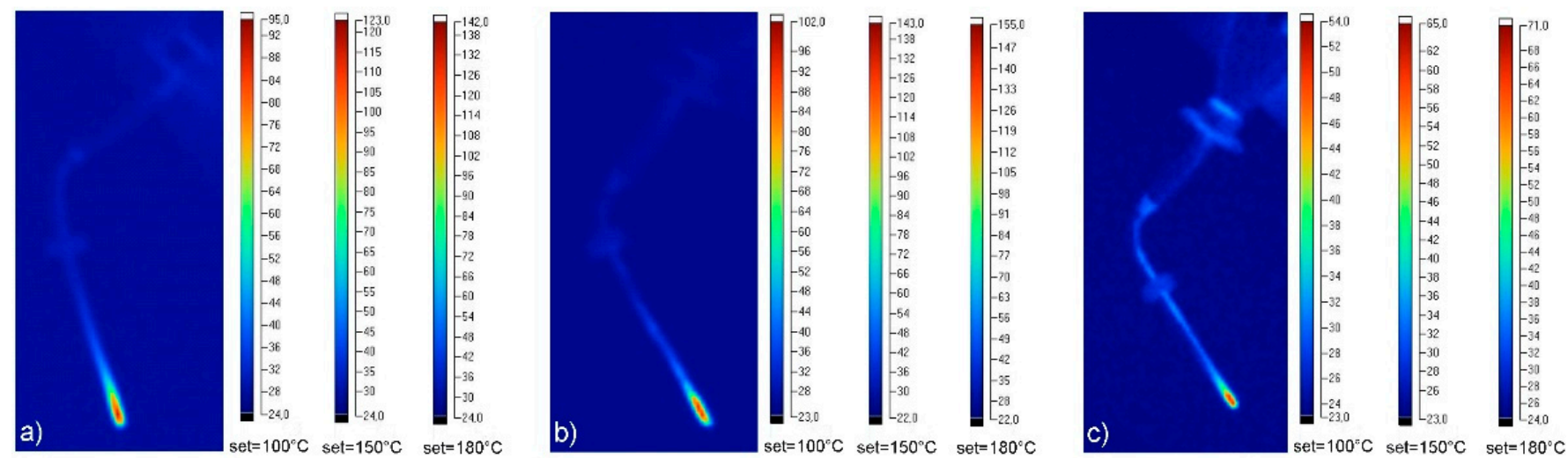

Figure 3. Temperature profiles along the pluggers at temperature settings of $100{ }^{\circ} \mathrm{C}, 150{ }^{\circ} \mathrm{C}$, and $180^{\circ} \mathrm{C}$. F-06 plugger (a); XF-30/04 plugger (b); and ML-12 plugger (c). Along the scale bar, it is possible to see the temperature profiles obtained by each heating system at different temperature settings.

\subsubsection{F-06 Plugger}

Statistically significant higher temperature peak levels $(p<0.05)$ were recorded by the T10mm thermocouple using the F-06 plugger irrespective of the temperature settings (Figure 4), suggesting that the $\mathrm{NaOCl}$ solution located in the middle third region of the root had the highest temperature levels. Concerning the T5mm thermocouple, registered temperature peak levels were higher $(p<0.05)$ than the apical region $(\mathrm{Ta})$, at all evaluated temperature settings. The Text thermocouple recorded a peak temperature of $50.1^{\circ} \mathrm{C}$ $\left( \pm 3.9^{\circ} \mathrm{C}\right.$ ) by setting the heating system at $180^{\circ} \mathrm{C}$ (Figure $4 \mathrm{c}$ ), and this value was significantly higher $(p<0.05)$ than that of $42.9^{\circ} \mathrm{C}\left( \pm 3.1^{\circ} \mathrm{C}\right)$ obtained at a setting of $100^{\circ} \mathrm{C}$ (Figure $4 \mathrm{a}$ ). Temperature increases of $2.5^{\circ} \mathrm{C}, 3.3^{\circ} \mathrm{C}$, and $4{ }^{\circ} \mathrm{C}$ were recorded by the thermocouple Ta at the settings of $100{ }^{\circ} \mathrm{C}, 150{ }^{\circ} \mathrm{C}$, and $180{ }^{\circ} \mathrm{C}$, respectively. At all temperature settings, the starting temperature recorded by the Tc thermocouple positioned in the cervical third region was slightly lower than that obtained by the other thermocouples (Figure 4). In addition, the temperature profile recorded by the Tc quickly dropped to values close to room temperature when the $\mathrm{NaOCl}$ solution was injected into the canal, then it quickly increased as the heating plugger was activated. Temperature peak levels of the Tc were 40.2 $\left( \pm 4.8^{\circ} \mathrm{C}\right), 44.7\left( \pm 5.1^{\circ} \mathrm{C}\right)$, and $50.5\left( \pm 5.7^{\circ} \mathrm{C}\right)$ at $100^{\circ} \mathrm{C}, 150{ }^{\circ} \mathrm{C}$, and $180^{\circ} \mathrm{C}$, respectively. 

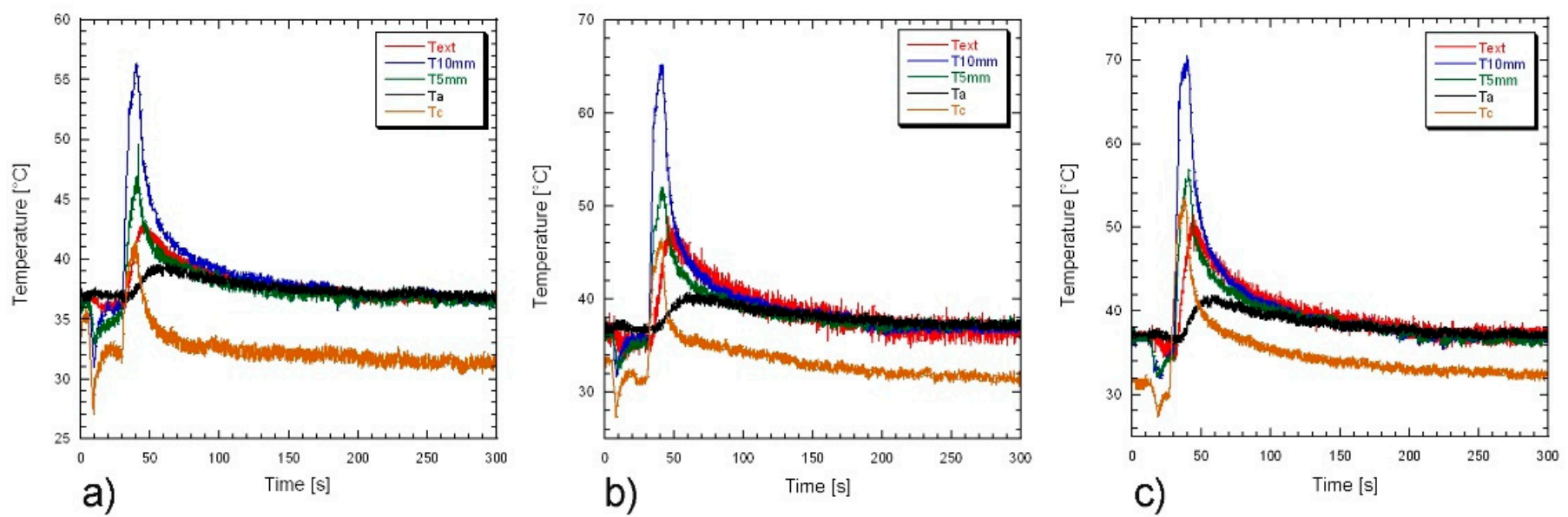

Figure 4. Temperature profiles in different regions of the tooth by heating sodium-hypochlorite through the F-06 plugger using temperature set at $100{ }^{\circ} \mathrm{C}(\mathbf{a}), 150{ }^{\circ} \mathrm{C}(\mathbf{b})$, and $180{ }^{\circ} \mathrm{C}$ (c).

\subsubsection{XF-30/04 Plugger}

Higher temperature levels were observed with the T5mm thermocouple using the XF-3004 plugger (Figure 5). However, the peak recorded by the T5mm thermocouple was not significantly higher than that of the T10mm, irrespective of the temperature settings. Conversely, the peak recorded by the T5mm thermocouple was statistically higher $(p<0.05)$ than the Text, Ta, and Tc. Temperature profiles of the Ta and Text using XF-30/04 plugger (Figure 5) were similar to those reported for the F-06 plugger (Figure 4). In particular, the Text showed a peak temperature of $51.2{ }^{\circ} \mathrm{C}\left( \pm 4.3^{\circ} \mathrm{C}\right)$ at $180^{\circ} \mathrm{C}$ (Figure $5 \mathrm{c}$ ), significantly higher $(p<0.05)$ than that of $41.6\left( \pm 3.6^{\circ} \mathrm{C}\right)$ obtained at a setting of $100{ }^{\circ} \mathrm{C}$ (Figure 5a). A temperature increase of $4.8^{\circ} \mathrm{C}\left( \pm 0.9^{\circ} \mathrm{C}\right)$ was registered by the thermocouple Ta at $180^{\circ} \mathrm{C}$. Similar to the F-06 plugger, the temperature profile recorded by the Tc quickly dropped to values close to room temperature as the $\mathrm{NaOCl}$ solution was injected into the canal, then it increased as the XF-30/04 plugger was activated. Temperature peak levels of Tc were 41.1 $\left( \pm 4.8^{\circ} \mathrm{C}\right), 42.7\left( \pm 4.2^{\circ} \mathrm{C}\right)$, and $51.8\left( \pm 4.9^{\circ} \mathrm{C}\right)$ at $100{ }^{\circ} \mathrm{C}, 150{ }^{\circ} \mathrm{C}$, and $180^{\circ} \mathrm{C}$, respectively.
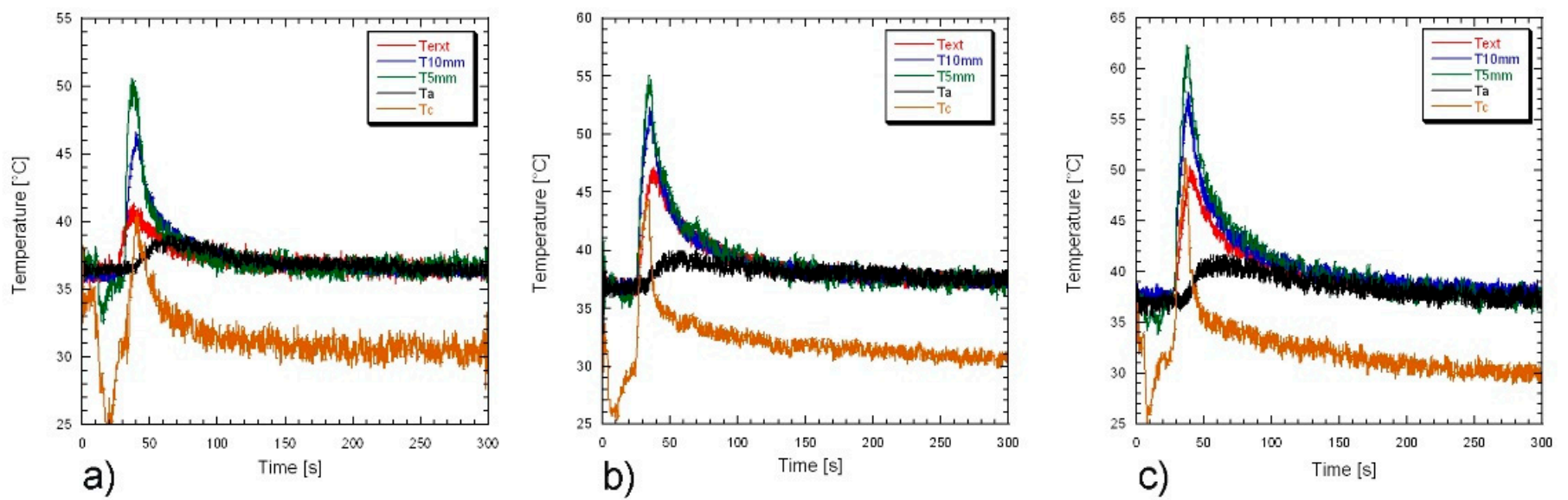

Figure 5. Temperature profiles in different regions of the tooth by heating sodium-hypochlorite through the XF-30/04 plugger using temperature set at $100{ }^{\circ} \mathrm{C}(\mathbf{a}), 150{ }^{\circ} \mathrm{C}(\mathbf{b})$, and $180{ }^{\circ} \mathrm{C}(\mathbf{c})$.

\subsubsection{ML-12 Plugger}

Temperature levels using the ML-12 plugger (Figure 6) were lower than those reported for the F-06 and XF-30/04 pluggers (Figures 4 and 5). This result was consistent with the lower temperature levels developed by the ML-12 plugger (Figure 2c). At all temperature settings, the peak level measured by the T10 $\mathrm{mm}$ was higher $(p<0.05)$ than those recorded by 
the T5mm, Ta, and Text (Figure 6). A slight temperature increase of about $2{ }^{\circ} \mathrm{C}$ was recorded by the $75 \mathrm{~mm}$ and Text thermocouples, as the plugger temperature was set at $180^{\circ} \mathrm{C}$ (Figure 6c). A remarkable temperature increase was measured by the Tc thermocouple, suggesting that the $\mathrm{NaOCl}$ solution located in the cervical third region of the root was at higher temperature levels.
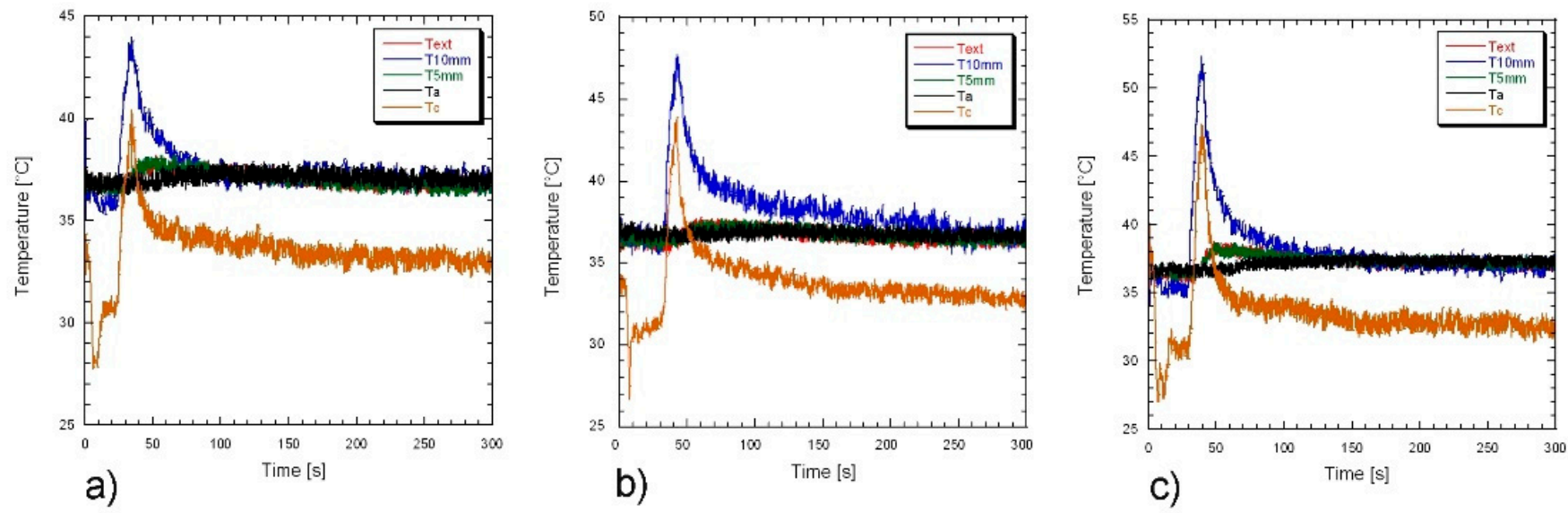

Figure 6. Temperature profiles in different regions of the tooth by heating sodium-hypochlorite through the ML-12 plugger using temperature set at $100{ }^{\circ} \mathrm{C}(\mathbf{a}), 150{ }^{\circ} \mathrm{C}(\mathbf{b})$, and $180{ }^{\circ} \mathrm{C}(\mathbf{c})$.

\subsection{Temperature Mantainance along the Root Canal}

Concerning the extraoral heating method, temperatures lower than $70{ }^{\circ} \mathrm{C}$ did not produce a significant temperature increase. On the other hand, in the case of heating at $70{ }^{\circ} \mathrm{C}$, the $\mathrm{T} 5 \mathrm{~mm}$ and $\mathrm{T} 10 \mathrm{~mm}$ thermocouples recorded a temperature level slightly higher than $40^{\circ} \mathrm{C}$ for $5.1 \mathrm{~s}$ and $5.8 \mathrm{~s}$, respectively (Table 1 ). Intracanal heating by the F-06 plugger at $100{ }^{\circ} \mathrm{C}$, showed temperature levels higher than $40^{\circ} \mathrm{C}$ for a significant prolonged time $(p<0.05)$ at the T5mm $(33.9 \mathrm{~s})$ and T10mm $(48.6 \mathrm{~s})$ thermocouples than that recorded for the extraoral heating method at $70{ }^{\circ} \mathrm{C}$ (Table 1$)$.

Table 1. Time interval (seconds) in which temperature at the apical and middle third regions of the root canal persisted higher than $40{ }^{\circ} \mathrm{C}, 50{ }^{\circ} \mathrm{C}$, or $60{ }^{\circ} \mathrm{C}$. Numbers in brackets represent the standard deviation.

\begin{tabular}{|c|c|c|c|c|c|c|c|c|}
\hline \multirow[b]{2}{*}{ Method } & \multirow[b]{2}{*}{$\begin{array}{c}\text { Temperature } \\
\text { Setting } \\
{\left[{ }^{\circ} \mathrm{C}\right]}\end{array}$} & \multicolumn{2}{|l|}{ Ta } & \multicolumn{2}{|l|}{ T5mm } & \multicolumn{3}{|c|}{$\mathrm{T} 10 \mathrm{~mm}$} \\
\hline & & $\begin{array}{l}\Delta t[s] \text { for } \\
T>40^{\circ} \mathrm{C}\end{array}$ & $\begin{array}{l}\Delta \mathrm{t}[\mathrm{s}] \text { for } \\
\mathrm{T}>40^{\circ} \mathrm{C}\end{array}$ & $\begin{array}{c}\Delta t[s] \text { for } \mathrm{T} \\
>50{ }^{\circ} \mathrm{C}\end{array}$ & $\begin{array}{c}\Delta \mathrm{t}[\mathrm{s}] \text { for } \mathrm{T} \\
>60^{\circ} \mathrm{C}\end{array}$ & $\begin{array}{c}\Delta t[s] \text { for } \\
\mathrm{T}>40^{\circ} \mathrm{C}\end{array}$ & $\begin{array}{c}\Delta t[s] \text { for } \mathrm{T} \\
>50{ }^{\circ} \mathrm{C}\end{array}$ & $\begin{array}{l}\Delta \mathrm{t}[\mathrm{s}] \text { for } \mathrm{T} \\
\quad>60{ }^{\circ} \mathrm{C}\end{array}$ \\
\hline \multirow{3}{*}{$\begin{array}{l}\text { Extraoral } \\
\text { heating }\end{array}$} & 50 & - & - & - & - & - & - & - \\
\hline & 60 & - & - & - & - & - & - & - \\
\hline & 70 & - & $5.1(2.8)$ & - & - & $5.8(3.1)$ & - & - \\
\hline \multirow{3}{*}{$\begin{array}{l}\text { SystemB } \\
\text { F-06 }\end{array}$} & 100 & - & $33.9(5.0)$ & - & - & $48.6(7.4)$ & $10.2(4.8)$ & - \\
\hline & 150 & $1.2(0.7)$ & $57.0(7.4)$ & $5.5(2.9)$ & - & $82.8(8.1)$ & $14.9(5.2)$ & $8.8(3.7)$ \\
\hline & 180 & $48.0(7.2)$ & $83.5(8.2)$ & $9.0(3.6)$ & - & 89.8 (7.9) & $19.7(5.8)$ & $10.5(4.1)$ \\
\hline \multirow{3}{*}{$\begin{array}{l}\text { SystemB } \\
\text { XF-30/04 }\end{array}$} & 100 & - & $27.3(5.6)$ & $2.8(1.4)$ & - & $25.7(5.1)$ & - & - \\
\hline & 150 & $0.9(0.5)$ & $74.1(9.1)$ & $8.2(3.1)$ & - & $61.1(5.8)$ & $5.5(2.8)$ & - \\
\hline & 180 & $57.6(6.3)$ & $108.4(9.8)$ & $18.2(5.8)$ & $3.3(1.2)$ & $101.6(13.8)$ & $14.4(4.9)$ & - \\
\hline \multirow{3}{*}{$\begin{array}{l}\text { SystemB } \\
\text { ML-12 }\end{array}$} & 100 & - & & - & - & $29.1(4.8)$ & - & - \\
\hline & 150 & - & & - & - & $29.8(4.9)$ & - & - \\
\hline & 180 & - & & - & - & $36.2(5.4)$ & $4.0(2.1)$ & - \\
\hline
\end{tabular}

According to the results of the present study, the extraoral heating method was ineffective to produce a significant temperature increase at the apex of the root, as suggested 
by the Ta thermocouple. Similar results were obtained using the intracanal heating method through the ML-12 plugger. Only by using a setting level of $180^{\circ} \mathrm{C}$ was it possible to observe a remarkable time interval through which the apical region was at a temperature higher than $40{ }^{\circ} \mathrm{C}$ (Table 1$)$.

\section{Discussion}

Heating of the $\mathrm{NaOCl}$ solution used as intracanal irrigant would increase cleanliness and the decontamination potential of the root canal system [6], although ideal $\mathrm{NaOCl}$ concentration and temperature should be further evaluated [11]. Moreover, the maintenance of a high intracanal temperature strictly depends on the heating procedures and on heat dissipation. Therefore, the aim of the present in vitro study was to compare the efficacy of different methods of $\mathrm{NaOCl}$ heating evaluating the temperature levels reached at different regions of root canal system as well as time interval of high temperature level persistence.

According to our results, the extraoral heating method was ineffective to produce significant temperature increase at the root apex. As previously reported, preheating of irrigants resulted in a marked intracanal temperature increase during its delivery and a quick drop thereafter [12]. A slightly better temperature increase was observed when the $\mathrm{NaOCl}$ solution was heated at $70^{\circ} \mathrm{C}$. Conversely, it was reported that a $60^{\circ} \mathrm{C}$ preheating of $\mathrm{NaOCl}$ resulted in significantly higher intracanal temperatures than other evaluated activation systems [13]. Accordingly, Leonardi et al. suggested that the preheating irrigant at $60^{\circ} \mathrm{C}$ and temperature maintenance with thermal activation may be considered an optimal irrigation protocol [14]. However, it is worth noting that temperature profiles recorded by the $\mathrm{T} 5 \mathrm{~m}$ and $\mathrm{T} 10 \mathrm{~m}$ thermocouples for the $\mathrm{NaOCl}$ solution heated at $70^{\circ} \mathrm{C}$ into the glass beaker, aspirated into the syringe, and injected into the root canal were similar to those recoded by Donnermeyer et al. [13] as the $\mathrm{NaOCl}$ water solution was directly preheated into the syringe at $60^{\circ} \mathrm{C}$, thus, suggesting a cooling of about $10^{\circ} \mathrm{C}$ as the $\mathrm{NaOCl}$ solution at $70{ }^{\circ} \mathrm{C}$ was aspirated into the graduated syringe.

Comparable results to extraoral heating were obtained using the intracanal heating method through the ML-12 plugger that showed slightly better results (temperature $>40$ and $50{ }^{\circ} \mathrm{C}$ ) only when set at $180^{\circ} \mathrm{C}$. The ML-12 plugger demonstrated lower temperature peak levels when compared to F-06 and XF-30/04; on the other hand, the latter reported the highest temperature peak levels, close to the setting temperature of the heating system.

The F-06 plugger demonstrated the highest temperature levels of the $\mathrm{NaOCl}$ solution located in the middle third region of the root $(\mathrm{T} 10 \mathrm{~mm})$. Similar results were obtained even with the XF-30/04 plugger that did not show significant differences between the T5mm and T10mm thermocouples; however, the outcomes registered at other levels of the root reported significantly lower temperature levels. In addition, negligible differences were observed in terms of temperature maintenance at several levels of the root between the F-06 and XF-30/04 pluggers, even though the time intervals were higher in the case of the XF-30/04.

The obtained results support the use of intracanal heating systems that allow a better temperature persistence and may enable the use of $\mathrm{NaOCl}$ at a lower concentration, maintaining the ability to dissolve organic tissue [15-17]. Nevertheless, it has been reported that final irrigation with $\mathrm{NaOCl}$ at different temperatures resulted in similar antibacterial effectiveness, even though hot $\mathrm{NaOCl}\left(45^{\circ} \mathrm{C}\right)$ caused higher postoperative pain levels than the same solution used cold $\left(2^{\circ} \mathrm{C}\right)$ [18]. In addition, thermal stimulation of the surrounding tissues as well as temperature dissipation should be taken into account and need to be further evaluated in future studies [6].

Noteworthy is the potential effect of temperature on NiTi endodontic files. Indeed, it has been demonstrated that the enhancement of intracanal temperature by heating $\mathrm{NaOCl}$ resulted in a decrease in the fatigue resistance of the rotatory endodontic instruments [19]. Moreover, it has been reported that intracanal temperature affected the cyclic fatigue of NiTi instruments, although it did not influence the fatigue of gold files [20]. This difference concerning the alloy [21], as well as the impact of the higher temperature on endodontic 
files, should be further developed to improve the instruments' mechanical performances and increase the success of endodontic treatment.

Even though the present study demonstrated the effectiveness of intracanal heating by System B pluggers, future research should consider newly developed heating instruments and should compare the obtained results with other methods used to activate endodontic irrigants.

\section{Conclusions}

Within the limitation of the present in vitro study, the intracanal heating method provided a better temperature persistence in the middle third of the root canal system. Conversely, extraoral heating was ineffective to produce a significant temperature increase at the apex of the root. Comparable results were obtained even using the ML-12 plugger.

Author Contributions: Conceptualization, R.D.S.; methodology, V.G.; validation, R.D.S., F.I. and G.S.; formal analysis, V.L.; investigation, V.G.; data curation, V.L.; writing—original draft preparation, F.I.; writing - review and editing, M.S. and G.S.; supervision, G.S. and C.R. All authors have read and agreed to the published version of the manuscript.

Funding: This research received no external funding.

Institutional Review Board Statement: The study was conducted in accordance with the Declaration of Helsinki and approved by the Institutional Review Board of the University of Naples Federico II (protocol n. 1372017).

Informed Consent Statement: Informed consent was obtained from all subjects involved in the study.

Data Availability Statement: The data presented in this study are available on request from the corresponding author.

Conflicts of Interest: The authors declare no conflict of interest.

\section{References}

1. JOE Editorial Board. Success and failure in endodontics: An online study guide. J. Endod. 2008, 34, e1-e6. [CrossRef] [PubMed]

2. Del Carpio-Perochena, A.; Monteiro Bramante, C.; Hungaro Duarte, M.; Bombarda de Andrade, F.; Zardin Graeff, M.; Marciano da Silva, M.; Cavalini Cavenago, B.; Lucas Fernandes, S. Effect of Temperature, Concentration and Contact Time of Sodium Hypochlorite on the Treatment and Revitalization of Oral Biofilms. J. Dent. Res. Dent. Clin. Dent. Prospect 2015, 9, 209-215. [CrossRef]

3. Haapasalo, M.; Shen, Y.; Wang, Z.; Gao, Y. Irrigation in endodontics. Br. Dent. J. 2014, 216, 299-303. [CrossRef]

4. Ametrano, G.; D'Antò, V.; Di Caprio, M.P.; Simeone, M.; Rengo, S.; Spagnuolo, G. Effects of sodium hypochlorite and ethylenediaminetetraacetic acid on rotary nickel-titanium instruments evaluated using atomic force microscopy. Int. Endod. J. 2011, 44, 203-209. [CrossRef] [PubMed]

5. Spagnuolo, G.; Ametrano, G.; D’Antò, V.; Formisano, A.; Simeone, M.; Riccitiello, F.; Amato, M.; Rengo, S. Microcomputed tomography analysis of mesiobuccal orifices and major apical foramen in first maxillary molars. Open. Dent. J. 2012, 6, 118-125. [CrossRef]

6. Tartari, T.; Borges, M.M.B.; de Araújo, L.B.B.; Vivan, R.R.; Bonjardim, L.R.; Duarte, M.A.H. Effects of heat in the properties of $\mathrm{NaOCl}$ alone and mixed with etidronate and alkaline tetrasodium EDTA. Int. Endod. J. 2021, 54, 616-627. [CrossRef] [PubMed]

7. Giardino, L.; Mohammadi, Z.; Beltrami, R.; Poggio, C.; Estrela, C.; Generali, L. Influence of Temperature on the Antibacterial Activity of Sodium Hypochlorite. Braz. Dent. J. 2016, 27, 32-36. [CrossRef]

8. Kamburis, J.J.; Barker, T.H.; Barfield, R.D.; Eleazer, P.D. Removal of organic debris from bovine dentin shavings. J. Endod. 2003, 29, 559-561. [CrossRef]

9. Gulsahi, K.; Tirali, R.E.; Cehreli, S.B.; Karahan, Z.C.; Uzunoglu, E.; Sabuncuoglu, B. The effect of temperature and contact time of sodium hypochlorite on human roots infected with Enterococcus faecalis and Candida albicans. Odontology 2014, 102, 36-41. [CrossRef]

10. Sirtes, G.; Waltimo, T.; Schaetzle, M.; Zehnder, M. The effects of temperature on sodium hypochlorite short-term stability, pulp dissolution capacity, and antimicrobial efficacy. J. Endod. 2005, 31, 669-671. [CrossRef]

11. Dumitriu, D.; Dobre, T. Effects of Temperature and Hypochlorite Concentration on the Rate of Collagen Dissolution. J. Endod. 2015, 41, 903-906. [CrossRef] [PubMed]

12. Macedo, R.G.; Verhaagen, B.; Versluis, M.; van der Sluis, L. Temperature evolution of preheated irrigant injected into a root canal ex vivo. Clin. Oral. Investig. 2017, 21, 2841-2850. [CrossRef] [PubMed] 
13. Donnermeyer, D.; Schäfer, E.; Bürklein, S. Real-time intracanal temperature measurement comparing mechanically and laseractivated irrigation to syringe irrigation. Aust. Endod. J. 2021, 47, 59-66. [CrossRef]

14. Leonardi, D.P.; Grande, N.M.; Tomazinho, F.S.F.; Marques-da-Silva, B.; Gonzaga, C.C.; Baratto-Filho, F.; Plotino, G. Influence of activation mode and preheating on intracanal irrigant temperature. Aust. Endod. J. 2019, 45, 373-377. [CrossRef] [PubMed]

15. Orlowski, N.B.; Schimdt, T.F.; Teixeira, C.D.S.; Garcia, L.D.F.R.; Savaris, J.M.; Tay, F.R.; Bortoluzzi, E.A. Smear Layer Removal Using Passive Ultrasonic Irrigation and Different Concentrations of Sodium Hypochlorite. J. Endod. 2020, 46, 1738-1744. [CrossRef] [PubMed]

16. Tartari, T.; Wichnieski, C.; Bachmann, L.; Jafelicci, M., Jr.; Silva, R.M.; Letra, A.; van der Hoeven, R.; Duarte, M.A.H.; Bramante, C.M. Effect of the combination of several irrigants on dentine surface properties, adsorption of chlorhexidine and adhesion of microorganisms to dentine. Int. Endod. J. 2018, 51, 1420-1433. [CrossRef] [PubMed]

17. Stojicic, S.; Zivkovic, S.; Qian, W.; Zhang, H.; Haapasalo, M. Tissue dissolution by sodium hypochlorite: Effect of concentration, temperature, agitation, and surfactant. J. Endod. 2010, 36, 1558-1562. [CrossRef] [PubMed]

18. KarataŞ, E.; Ayaz, N.; UlukÖylÜ, E.; Baltaci, M.O.; AdigÜzel, A. Effect of final irrigation with sodium hypochlorite at different temperatures on postoperative pain level and antibacterial activity: A randomized controlled clinical study. J. Appl. Oral. Sci. 2021, 29, e20200502. [CrossRef]

19. Alfawaz, H.; Alqedairi, A.; Alsharekh, H.; Almuzaini, E.; Alzahrani, S.; Jamleh, A. Effects of sodium hypochlorite concentration and temperature on the cyclic fatigue resistance of heat-treated nickel-titanium rotary instruments. J. Endod. 2018, 44, 1563-1566. [CrossRef]

20. Plotino, G.; Grande, N.M.; Mercade-Bellido, M.; Testarelli, L.; Gambarini, G. Influence of temperature on cyclic fatigue resistance of ProTaper Gold and ProTaper Universal rotary files. J. Endod. 2017, 43, 200-202. [CrossRef]

21. Martins, J.N.R.; Silva, E.J.N.L.; Marques, D.; Pereira, M.R.; Ginjeira, A.; Silva, R.J.C.; Braz Fernandes, F.M.; Versiani, M.A. Mechanical performance and metallurgical features of ProTaper Universal and 6 replicalike systems. J. Endod. 2020, 46, $1884-1893$. [CrossRef] [PubMed] 